Marquette University

e-Publications@Marquette

Marketing Faculty Research and Publications

Business Administration, College of

4-1-1993

Marketing Ethics: Onward Toward Greater

Expectations

Gene R. Laczniak

Marquette University, eugene.laczniak@marquette.edu

Published version. Journal of Public Policy \& Marketing, Vol. 12, No. 1 (Spring 1993): 91-96.

Publisher Link. (C) 1993 American Marketing Association. Used with permission. 


\title{
Marketing Ethics: Onward Toward Greater Expectations
}

\author{
Gene R. Laczniak
}

This article introduces a set of articles selected for this special JPP\&M "Symposium on Marketing Ethics." It also provides a brief overview of the evolution of marketing ethics research during the past decade. Several suggestions for the future development of marketing ethics research are advanced and discussed.

\section{The State of Marketing Ethics Research}

More than 12 years ago, Patrick Murphy and I reviewed the published literature on marketing ethics [Murphy and Laczniak 1981]. We found it to be relatively unbalanced, nonmainstream, and lacking empiricism. It was unbalanced in the sense that such areas as advertising [Galbraith 1958; Packard 1957] and marketing research ethics [Bogart 1962; Tybout and Zaltman 1974] received the preponderance of attention, whereas other important topics such as pressures on channel members and product issues were seldom addressed. It was nonmainstream in that many of the articles on marketing ethics were published in low visibility outlets such as specialty proceedings [cf. Boulding 1971] and trade journals [cf. Cummings 1979]. It was nonempirical in that the publications consisted largely of normative "thou shalt not" articles [cf. Pruden 1971] or simple surveys of how practitioners [cf. Crawford 1970] or members of the public felt about various ethical practices in marketing [cf. Baumhart 1968]. In short, the condition of marketing ethics research was less than robust.

Since then, much has happened for "the good," at least in terms of a demonstrated commitment by academicians to analyze the ethics of marketing practitioners. Academicians seem to have taken seriously one of the guiding purposes of the American Marketing Association: "to advance the...ethical practices of the marketing discipline" (AMA Mission Statement). In the past decade, there has been a broader coverage of marketing issues, greater academic visibility for publications addressing marketing ethics, and the development of a theoretical and empirical foundation for future research in this area [cf. Laczniak and Murphy 1985]. Brief comments on each of these points follow.

\section{Broader Coverage}

Marketing academicians now investigating a much wider variety of ethical issues and concerns, including topics such as the ethics of political marketing [Laczniak and Caywood 1987], packaging [Corey and Bone 1990], and the relationship among channel members [Gifford and Norris 1987]. Especially notable here is the ethical analysis of professional services marketing, which has grown rapidly as a result of landmark legal cases [Virginia State Board of Pharmacy $v$. Virginia Citizens Consumer Council and Bates v. State Bar

Gene R. LaczniaK is Professor of Marketing, Marquette University.
. of Arizona] that allow for advertising and promotion by professional practitioners such as physicians, attorneys, and accountants. Marketing ethics researchers have also been relatively quick to evaluate emerging social issues such as the "green marketing" phenomenon [cf. Berger and Corbin 1992].

\section{Greater Academic Visibility}

Many of the major marketing journals now regularly carry articles investigating ethical concerns in marketing. A purely illustrative listing might include the recent work of Fraedrich and Ferrell [1992], Goolsby and Hunt [1992], and Bellizzi and Hite [1989]. Moreover, the literature now includes two textbooks on marketing ethics [Laczniak and Murphy 1993; Smith and Quelch 1992]. Previously, such materials had to be culled from such widely disparate sources as sections of business ethics books that treated advertising ethics or consumerism in a relatively isolated fashion [cf. Valasquez 1982]. Perhaps most heartening is the treatment of marketing ethics in many current principles of marketing textbooks [cf. McCarthy and Perrault 1993]; in some instances the discussion of ethics has even been integrated throughout the work [Schoell and Guiltinan 1992]. It is noteworthy that grassroots interest in integrating ethics into the classroom remains high among many teaching academicians [Boatright 1991]. Many recent regional academic and AMA educator conferences have included sessions on teaching ethics. A sourcebook of applicable teaching materials for marketing ethics has also been assembled [Bol et al. 1991].

\section{The Development of Theoretical and Empirical Foundations}

The major advancement in marketing ethics research, in terms of knowledge development, has come in the form of the various models of marketing ethics [cf. Ferrell, Gresham, and Fraedrich, 1989]. Some of these models normatively attempt to assemble the various considerations that ought to be weighed in reaching an ethical marketing decision [Laczniak 1983]. Others more systematically describe the processes marketers use in adjudicating a marketing issue that raises ethical questions [Hunt and Vitell 1986; Robin and Reidenbach 1987]. Importantly, efforts are well under way to test empirically several of the postulated relationships [cf. Chonko and Hunt 1985]. Critically central to the purposes of this empirical research tradition is 
the further refinement of current models and the stimulation of additional conceptual and empirical work in ethics [Jones, T. 1991].

\section{JPP\&M Symposium on Marketing Ethics}

The contributions in this $J P P \& M$ symposium on marketing ethics add, in a measured way, to the momentum achieved by recent marketing ethics research. Such editorial commitment is important because many of the major public policy and regulatory issues flowing from marketing practice first arise and often remain as ethical issues in addition to legal questions. Therefore, identifying, analyzing, and conceptualizing ethical issues in marketing is central to the marketing/public policy interface. The symposium on marketing ethics is intended to stimulate future contributions that link ethical questions and their public policy implications.

In response to the call for papers for this symposium, 21 manuscripts were submitted for review. Three of these submitted papers are in this issue. The manuscripts evaluated represented almost all types of marketing ethics research being conducted, including practitioner surveys, interpretive analyses of emerging issues, model formulation, and empirical testing. The spectrum of topics covered is a further indication of the current "health" of marketing ethics research and the enduring commitment of a battery of scholars to such research. Some of the submissions, though of considerable merit, were judged by the reviewers to need additional revision and reformulation. Undoubtedly, some of them will eventually appear "new and improved" in this journal or other forums.

The symposium's lead article by Robin and Reidenbach is essentially a commentary on the nature of ethical theory that underpins recent critiques of marketing ethics. The authors unfold an eloquent case for cultivating revised expectations about what current ethical theory can provide in the relativistic world in which marketers do their deeds. Consistent with the tenets of deconstruction, the article lays out the attributes of time, history, and context, which constrain the appropriateness and unbridled application of deontologically based moral theories. Moreover, the article addresses the variables of social expectations, the assumptions of capitalistic systems, and various human foibles that shape realistic approaches to marketplace decisions. The authors incisively contend that now is the time for marketers to articulate and shape the new moral philosophy that they will live by.

Though also theoretical, the article by Duke and his colleagues proposes a conceptual framework by which to better implement the ethical analysis of marketing issues. Their model, labeled the ethical effects reasoning matrix (ERM), provides one approach for combining the stakeholder method so popular in the social responsibility literature [Freeman 1984; Goodpaster 1991] with the various theories of ethical reasoning used in marketing. A specific focus in this article is the fear appeal, which is often used as part of promotional strategy [LaTour and Pitts 1988]. This application provides a stern test for the usefulness of the ERM, because the fear appeal is the quintessential mar- keting ethics issue [Wheatley 1971]. The appropriateness of fear appeals is inherently illusive and subjective. Certainly, the creation of a modest amount of customer anxiety about some purchases merely illustrates the centrality of buying decisions to our consumer lives [Ray and Wilkie 1970]. But when does the evocation of modest anxiety slip into the creation and manipulation of customer fears? The ERM showcases an analytical procedure for attacking such questions and other ethical issues, while still granting that subjective management judgment cannot be eliminated. Though the authors do not so state, the ERM itself is an intriguing form of utilitarian analysis with many other pragmatic applications for marketing managers who are grappling with ethical issues.

The article by Foxman and Kilcoyne on information technology and consumer privacy is an insightful analysis of one aspect of an emerging issue in the United States. Using telephone caller ID as a springboard for their observations, the authors examine the ethical dimensions of marketing practice in relation to consumer privacy. This issue is crucial because marketers are a primary impetus in creating the motivation to develop technology that possibly violates consumer privacy as a side effect [Jones, M. 1991]. For example, the customer service and market research mentality generates a demand for detailed customer profiles, and the development of computerization allows the assembly of such databases. The ethical questions are why various information is gathered, how it is used, who has access to it, and whether consumers are informed about what happens to the information in their personal profile [Goodwin 1991]. It is startling to consider that for most consumers, a computerized record is made of many of their spending and travel patterns (from credit cards), the movies they rent, the books they read, their financial condition (from loan applications), health status (from insurance records), and much more. Potentially, through Social Security, credit cards, PINs, or other mechanisms, much of this information could be pulled together in one dataset. Routinely, when consumers make purchases, their names are recorded and rented to other merchandisers who offer related products. For instance, the ethics of certain cable TV systems has been questioned because they sold lists of consumers who ordered childrens' movies to companies selling "family" type products. One can easily imagine more embarrassing and intrusive scenarios involving similar data. In part, the Foxman and Kilcoyne article sets the historical and current context for this issue of consumer privacy - an area that demands additional reflection and empirical research.

\section{The Challenge of Marketing Ethics Research}

Taken together, these articles constitute a reasonably representative sampling of the type of marketing ethics research that might be undertaken. In the terminology of Hunt's [1976] three dichotomies model, research in marketing can be classified as micro/macro, normative/positive, and profit/ not-for-profit. Robin and Reidenbach offer a commentary on the factors required to refine descriptive (i.e., positive) models of marketing ethics. Duke and his colleagues pre- 
sent a micro/normative framework for analyzing fear-laden promotional campaigns that might be undertaken in the profit or nonprofit sector. Foxman and Kilcoyne normatively dissect the specifics of a recurring macro questionhow marketing affects consumer privacy. Marketing ethics research must proceed on all dimensions of the dichotomies model to have maximum value for the many constituencies of marketing (e.g., practitioners, consumers, regulators, academicians, students).

Absent in this symposium, however, are articles that test specific theories about managerial behavior related to marketing ethics (i.e., the micro/positive perspective). Several such manuscripts were submitted, but they were judged by reviewers to be deficient in some way in their current form. Such empirical research in ethics does indeed face unique methodological obstacles, though some exploratory efforts along these lines have been successful [cf. Mayo and Marks 1990; Reidenbach, Robin, and Dawson 1991; Singhapakdi and Vitell 1990]. As marketing ethics is a subset of business ethics, the refinements in this more general branch of research, in terms of developing empirical traditions, provide signposts for what might be done in the empirical testing sector of marketing ethics research [Frederick 1992; Trevino 1992].

Beyond the theory building and hypothesis testing inherent in knowledge development, marketing academicians ought to remain aware of their responsibility for knowledge transmission about marketing ethics in their capacity as educators of future business professionals. Current AACSB guidelines call for coverage of ethical issues throughout the curriculum. Marketers as well as other functional specialists must do their part to provide such information to the next generation of managers [Bishop 1992]. Possibly this obligation will lead to the development of a continuous stream of cases describing ethical situations in marketing [cf. Schaupp, Ponzurick, and Schaupp 1992], classroom exercises that raise ethical concerns [Bol et al. 1991], and the publication of essays and op/ed pieces in which marketing academicians take a stand on controversial marketing practices and their public policy implications.

\section{The Practice of Higher Ethical Standards In Marketing}

One question that remains is whether the flurry of research on ethical questions in marketing has affected the ethical climate of marketing practice. From a strictly social science standpoint, the answer to this query must be "we don't know." Reports of questionable activity relating to marketing practice continue to appear regularly in newspapers. Some threshold of manipulative advertising, exploitive new products, and deceptive pricing, to name a few categories, seems destined to remain part of the social landscape, much like crime, higher taxes, and unemployment. Public opinion polls about the state of business and marketing ethics, though not without variability, tend to show an enduring baseline level of consumer skepticism and disapproval [Laczniak and Murphy 1993].

Does this mean marketing educators cannot improve the ethical climate of marketing practice? Some social observ- ers have contended that ethics cannot be taught to managers because their values are already formed and relatively immutable [Miller and Miller 1976]. I doubt that this notion is valid [cf. Weber 1990]. Certainly numerous documented cases of how managerial actions can be influenced by economic conditions or organizational pressures have been reported [Smith and Quelch 1992]. If "proper" action is contingency based, steps can be taken to shape managerial values and/or change the organizational environment [cf. Ferrell and Gresham 1985]. The pragmatic implementation of efforts to teach ethics and improve organizational conduct is already underway in many companies [Murphy 1988]. Undoubtedly, there will always be unethical marketing managers, just as there are unethical politicians, lawyers, clerics, and college professors. Moreover, given the diversity of human personalities and backgrounds, different types of managers will try to resolve ethical issues in different ways. Consider the following nominal classification of marketing managers:

- Crooks, who know what is right but will very often act unethically to achieve personal or organizational gain.

- Legalists, who have no use for theories of business ethics. Their view is that if it's legal, it's acceptable.

- Moralists, the "good neighbor" managers who always try to do the right thing - men and women of principle.

- Seekers, the managers who want to do the right thing but do not always recognize the true complexity of ethical situations and/or do not completely comprehend ethical consequences.

- Rationalizers, the managers who typically recognize the presence of an ethical problem, but often rationalize their way to an economically expedient solution; they typically give lip service to ethics, but do not always practice business moral $\frac{\text { tyy }}{1 y}$.

Managers who are outright crooks and the relatively saintly ones who are moralists are hypothesized to be much less common than seekers, rationalizers, and legalists [Laczniak and Murphy 1993]. If this is so, such a condition has implications for marketing educators. Managers who do not regularly recognize the ethical implications of their decisions (i.e., rationalizers) are in need of heightened ethical sensitivity and training through ethics education. Those who recognize situations with moral consequences but cannot properly address them are in need of exercises in ethical reasoning. Those who see only a legalist response to an ethical problem may benefit from a knowledge of ethical theory. The opportunity to provide needed education to marketing managers makes it all the more important for marketing educators to pursue the moral imperative of enlightening future administrators about their professional responsibility to serve not only their organization, but society.

\section{The Future of Marketing Ethics Research}

As marketing ethics research unfolds over the next 10 years, what developments would be desirable? A few items, not meant to represent an exhaustive list, are enumerated here. 
Marketing Ethics

\section{Alternative Paradigms}

The past decade of fruitful work in marketing ethics has been of two broad directions. First, normative ethical theory, drawn from moral philosophy, has been brought to bear on marketing problems [cf. Williams and Murphy 1990]. Second, positive models of marketing ethics, which describe the factors influencing ethical decisions, have been formulated and partially tested [cf. Hunt and Vitell 1986]. There now appears to be a window of opportunity for alternative interpretations and exhortations about marketing ethics drawn from diverse schools of thought such as humanistic inquiry, feminist criticism, deconstruction, and Eastern religions. Such alternative approaches, though they may not be quickly appreciated by the discipline, have the potential to provide new perspectives for understanding difficult ethical problems and generating innovative solutions.

\section{Cross-Cultural Evaluation}

Global competition and international markets are a reality for most organizations of any size or scope. The challenge of operating in a global economy means that organizations must address a broader latitude of ideas, philosophies, traditions, religions, societal expectations, and moral norms [Laczniak and Naor 1985]. Clearly, the international application of ethical codes or guidelines that might be the product of a single cultural experience (e.g., U.S.) is tenuous. An immediate challenge for marketing ethics researchers is to undertake cross-cultural studies of ethical issues in marketing and to compare and contrast the beliefs and practices of a wide spectrum of culturally diverse managers and companies [Buller, Kohls, and Anderson 1991]. The cynical first response to this challenge might be that few global ethical dicta will be uncovered. Perhaps. A more open-minded initial position could be that within the increasingly homogeneous economic culture of global corporations, patterns of behavioral similarity and ethical expectations might be emerging [cf. Wines and Napier 1992].

\section{Gap Analysis}

Marketing ethics researchers have historically done a good job of gauging the typical ethical disposition of their fellow practitioners [cf. Akaah and Riordan 1989; Ferrell and Weaver 1978]. Added to this knowledge in the past decade has been the systematic specification of factors leading to these dispositions [cf. Robin 1988; Trevino 1986]. This information has come in the form of the models of marketing ethics discussed previously [cf. Ferrell, Gresham, and Fraedrich 1989; Hunt and Vitell 1986]. At the same time, society has expectations of marketing practioners that may be at variance with (i.e., higher than) the level at which marketers have been performing. Similarly, marketers' expectations about their own professional behavior may exceed their actual collective actions. In the first instance, where society requires better ethical conduct from marketers than they are providing, there is a societal expectations/ethical reality gap. In the second case, where the marketing profession desires improved ethical performance from marketers, there is a professional expectation/ethical reality gap. The immedi- ate challenge for marketing ethics researchers is to chart these gaps across a wide variety of ethical issues, market contexts, and competitive situations. Normatively, the longer term charge is to offer managers reasonable strategies to reduce any documented expectation/reality gaps. For these strategies to be most readily accepted and implemented, marketing ethics researchers ought to show, whenever possible, how improved ethical performance is consistent with marketing's enduring philosophy of long-run customer orientation. This last observation leads to a concluding point.

\section{Informed Advocacy}

One of the few negative aspects of the recent emphasis on building and testing descriptive models of marketing ethics has been the relative lack of judgmental comment on what these models philosophically imply. To a degree, this lack is understandable. For years, implicitly drawing on the Judeo-Christian heritage of the U.S., much of the analysis of business ethics took the form of quasireligious admonitions. The purpose of formulating systematic models of marketing ethics was to describe clinically what marketers actually do when facing ethical questions. Eventually, model builders rightfully hope to be able to predict and explain the behavior of marketing practioners when they make ethical choices [cf. Hunt and Chonko 1984]. However, this nonjudgmental approach to looking at the behavior of marketing managers ignores an important aspect of ethics. It is this: the very point of studying ethics-at least in its original, classical conception-is to understand more fully the pathway to making morally correct decisions [Aristotle, Nichmachean Ethics]. In essence, ethical knowledge enables managers to become better persons by doing what is right, just, and good. As a byproduct, managers ennoble themselves, their organizations, and others. Too often in doing descriptive modeling, marketing ethics researchers have eschewed the opportunity to comment critically on the moral implications of their findings [Frederick 1986; Kahn 1990]. For instance, if it turns out that marketers are more "'manipulative" (by some operational measure) than other groups, marketers ought to ask: "What are the societal impacts of this state of affairs? Does this hypothetical situation bode well or ill for how business, and the marketing function, serves the economic goals of society? How should things be changed? How can ethical marketing practice be enhanced?" These are tough, debatable questions and the answers are elusive. The attempted "value neutrality" of the academic mindset often impels researchers to leave such subjective judgment calls to others. But to whom? Politicians? TV evangelists? Lawyers? As members of the academy, marketing academicians have the freedom to think about as well as analyze the major issues in their field. With this freedom comes their responsibility as experts to provide suggestions-to profess-about how that system can be improved. Future public perceptions of marketing may depend on academicians' willingness to assume the role of informed advocate for improved ethical practice by marketing managers. 


\section{References}

Akaah, Ishmael P. and Edward A. Riordan (1989), “Judgments of Marketing Professionals About Ethical Issues in Marketing Research: A Replication and Extension," Journal of Marketing Research, 26 (February), 112-20.

Bates v. State Bar of Arizona / (1977), 433 v.5. 350,53 L. Ed. 2d 810 , $975 . C * .26 \% 1$.

Baumhart, Raymond C. (1961), "How Ethical Are Businesses?" Harvard Business Review, 39 (July-August), 6.

(1968), Ethics in Business. New York: Holt, Rinehart and Winston, Inc.

Bellizzi, Joseph A. and Robert E. Hite (1989), “'Supervising Unethical Salesforce Behavior,” Journal of Marketing, 53 (April), 36-47.

Berger, Ida E. and Ruth M. Corbin (1992), “Perceived Consumer Effectiveness and Faith in Others as Moderators of Environmentally Responsible Behaviors," Journal of Public Policy \& Marketing, 11 (Fall), 79-89.

Bishop, Terrence R. (1992), “Integrating Business Ethics Into an Undergraduate Curriculum," Journal of Business Ethics, 11, 291-9.

Boatright, J. R. (1991), "From Theory to Practice: Faculty Training in Business Ethics," Moral Education Forum, (Winter), 7$13+$.

A (4)

Bogart, Leo (1962), "The Researcher's Dilemma," Journal of Marketing, 26 (January), 6-11.

Bol, Jan Willem, Charles T. Crespy, James M. Stearns, and John R. Walton (1991), The Integration of Ethics in the Marketing Curriculum: An Educator's Guide. Needham Heights, MA: Ginn Press.

Boulding, Kenneth (1971), “The Ethics of Persuasion," paper presented by AMA Educators' Conference, Minneapolis, MN (August 30).

Buller, P., J. Kohls, and K. Anderson (1991), "The Challenge of Global Ethics,” Journal of Business Ethics, 10 (10), 767-75.

Coyd,Clarke L Gene R. Laczniak (1990), "The Marketing-of-Politioal-Candidates:-Eurrent-Factics and Future-Strategies," in-iat Marketing, S. Fine, ed. Boston: Allyn \& Bacom, 233-57

Chonko Lawrence B. and Shelby D. Hunt (1985), "Ethics and Marketing Management: An Empirical Examination,” Journal of Business Research, 339-59.

Corey, R. J. and P. F. Bone (1990), "Ethical Packaging: Directions for the 1990s," in American Marketing Association Proceedings, ${ }_{\wedge}$ Chicago: American Marketing Association, 387.

Crawford, Merle C. (1970), "Attitudes of Marketing Executives Toward Ethics in Marketing Research," Joumal of Marketing, 34 (April), 46-52.

Cummings, Gary F. (1979), "AAre Purchasing Ethics Being Put to the Test?" Iron Age, 222 (September 24), 21-4.

Ferrell, O. C. and Larry G. Gresham (1985), “A Contingency Framework for Understanding Ethical Decision Making in Marketing," Journal of Marketing, 49 (Summer), 87-96.

and John Fraedrich (1989), "A Synthesis of Ethical Decision Models for Marketing," Journal of Macromarketing, 9, (Fall), 55-64.

and K. M. Weaver (1978), "Ethical Beliefs of Marketing Managers,” Journal of Marketing, 42 (July), 69-73.
Fraedrich, John and O. C. Ferrell (1992), “Cognitive Consistency of Marketing Managers in Ethical Situations," Journal of the Academy of Marketing Science, 20, (Summer), 245-52.

Frederick, William C. (1986), "Toward CSR3: Why Ethical Analysis is Indispensable and Unavoidable in Corporate Affairs," California Management Review, 28 (Winter), 126-41.

(1992), "The Empirical Quest for Normative Meaning: Introduction and Overview," Business Ethics Quarterly, 2 (April), 91-8.

Freeman, Edward R. (1984), Strategic Management: A Stakeholder Approach. Boston: Pitman Publishing.

Galbraith, John Kenneth (1958), The Affluent Society. Boston: Houghton-Mifflin Company.

Gifford, John B. and Donald G. Norris (1987), "Ethical Attitudes of Retail Store Managers: A Longitudinal Analysis," Journal of Retailing, (Fall), 302.

Goodpaster, K. E. (1991), "Business Ethics and Stakeholder Analysis,” Business Ethics Quarterly (January). 53-73.

Goodwin, Cathy (1991), "Privacy: Recognition' of a Consumer Right," Journal of Public Policy \& Marketing, 10 (Spring), 149-66.

Goolsby, Jerry R. and Shelby D. Hunt (1992), “Cognitive Moral Development and Marketing," Journal of Marketing, 56 (January), 55-68.

Hunt, Shelby D. (1976), "The Nature and Scope of Marketing," Journal of Marketing, 40 (July), 17-28.

and Lawrence B. Chonko (1984), "Marketing and Machiavellianism," Journal of Marketing, 48 (Summer), 30-42.

and Scott J. Vitell (1986), "A General Theory of Marketing Ethics," Journal of Macromarketing, (Spring), 5-16.

Jones, Mary Gardiner (1991), "Privacy: 'A Significane Marketing Issue for the 1990s," Journal of Public Policy \& Marketing, 10 (Spring), 133-48.

Jones, Thomas M. (1991), "Ethical Decision Making by Individuals in Organizations: An Issue-Contingent Model," Academy of Management Review, 16 (April), 366-95.

Kahn, William A. (1990), "Toward an Agenda for Business Ethics Research," Academy of Management Review, 15, 311-28.

Laczniak, Gene R. (1983), "Frameworks for Analyzing Marketing Ethics," Journal of Macromarketing (Spring), 7,18.

and Clark L. Caywood (1987), "The Case tor and Against Televised Political Advertising: Implications for Research and Public Policy," Journal of Public Policy \& Marketing, 6, 1632.

and Patrick E. Murphy (1985), Marketing Ethics: Guidelines for Managers. Lexington, MA: Lexington Books.

and __ (1993), Ethical Marketing Decisions: The Higher

Road. Boston: Allyn and Bacon, Inc.

and J. Naor (1985), "'Global Ethics: Wrestling with the Corporate Conscience," Business (July-August), 3-10.

LaTour, Michael S. and Robert E. Pitts (1988), "Using Fear Appeals in Advertising for AIDS Prevention in the College-Age Population," Journal of Health Care Marketing, 9 (September), 5-14.

Mayo, Michael A. and Lawrence J. Marks (1990), “An Empirical Investigation of a General Theory of Marketing Ethics," Journal of the Academy of Marketing Science, 18 (Spring), 163-71. 
McCarthy, E. J. and William D. Perreault, Jr. (1993), Basic Marketing. Homewood, IL: Richard D. Irwin, Inc.

Miller, M. S. and A. E. Miller (1976), "It's Too Late for Ethics Courses in Business Schools," Business and Society Review, $17,39-42$.

Murphy, Patrick E. (1988), “Implementing Business Ethics," Journal of Business Ethics, (December), 907-15.

and Gene R. Laczniak (1981), "Marketing Ethics: A Review With Implications for Managers, Educators and Researchers," in Review of Marketing, B. M. Enis and K. J. Roering, eds. Chicago: American Marketing Association, 251-66.

Packard, Vance (1957), The Hidden Persuaders. New York: Pocket Books.

Pruden, Henry O. (1971) "Which Ethics for Marketers?' in Marketing and Social Issues, John R. Wish and Stephen H. Gamble, eds. New York: John Wiley \& Sons, Inc., 98-104.

Ray, Michael L. and William L. Wilkie (1970), "Fear: The Potential of an Appeal Neglected by Marketing," Journal of Marketing, 34 (January), 54-62.

Reidenbach, R. Eric, Donald P. Robin, and Lyndon Dawson (1991), "An Application and Extension of a Multidimensional Ethics Scale to Selected Marketing Practices and Marketing Groups," Journal of the Academy of Marketing Science, 19 (Spring), 83-92.

Robin, Donald P. (1988), “A Framework for Analyzing Ethical Issues in Marketing," Business \& Professional Ethics Journal, 5, 3-22.

and R. Eric Reidenbach (1987), "Social Responsibility, Ethics, and Marketing Strategy: Closing the Gap Between Concept and Application," Journal of Marketing, 41 (January), 44-58.

Schaupp, Dietrich L., Thomas G. Ponzurick, and Frederick W. Schaupp (1992), "'The Right Choice: A Case Method for Teaching Ethics in Marketing," Journal of Marketing Education, (Spring), 1-11.

$14(2)$
Schoell, William F. and Joesph P. Guiltinan (1992), Marketing, 5th ed. Boston: Allyn and Bacon, Inc.

Singhapakdi, A. and Scott J. Vitell (1990), "Marketing Ethics: Factors Influencing Perceptions of Ethical Problems and Alternatives," Journal of Macromarketing, 10 (Spring), 4-18.

Smith, N. Craig and J. A. Quelch (1992), Ethics in Marketing. Homewood, IL: Richard D. Irwin, Inc.

Trevino, Linda Klebe (1986), "Ethical Decision Making in Organizations: A Person-Situation Interactionist Model," Academy of Management Review, 11 (July), 601-18.

(1992), “'Experimental Approaches to Studying EthicalUnethical Behavior in Organizations,"' Business Ethics Quarterly, 2 (April), 121-36.

Tybout, Alice M. and Gerald Zaltman (1974), "Ethics in Marketing Research: Their Practical Relevance," Journal of Marketing Research, 11 (November), 357-68.

Valasquez, M. G. (1982), Business Ethics: Concepts and Cases. Englewood Cliffs, NJ: Prentice-Hall, Inc.

Virginia State Board of Pharmacy v. Virginia Citizens ${ }^{2}$ Consumer Councile (1976) , 425 U.S. $748,48 \mathrm{~L}$. Ed. 2 d. $3+6$ 96 S.CT. 1817.

Weber, James (1990), "Measuring the Impact of Teaching Ethics to Future Managers: A Review, Assessment, and Recommendations," Journal of Business Ethics, 9, 183-90.

Wheatley, John J. (1971), "Marketing and the Use of Fear-Anxiety Appeals," Journal of Marketing, 35 (April), 62-4.

Williams, Oliver F. and Patrick E. Murphy (1990), "The Ethics of Virtue: A Moral Theory for Marketing," Journal of Macromarketing, 10 (Spring), 19-29.

Wines, William A. and Nancy K. Napier (1992), "Toward an Understanding of Cross-Cultural Ethics: A Tentative Model," Journal of Business Ethics, 11, 831-41. 